Jurnal Sulolipu : Media Komunikasi Sivitas Akademika dan Masyarakat

Vol. 17 No.II 2017

e-issn : 2622-6960, p-issn : 0854-624X

\title{
EFEKTIVITAS DAUN DAN BUNGA TANAMAN SUKUN (Artocarpus altilis) SEBAGAI ANTI NYAMUK MAT ELEKTRIK DALAM MEMBUNUH NYAMUK Aedes aegypti H. Hamsir Ahmad' dan Nurul Fahmi ${ }^{2}$ \\ 1,2Jurusan Kesehatan Lingkungan Poltekkes Kemenkes Makassar nurulfahmi06@gmail.com
}

\begin{abstract}
DHF is a disease caused by dengue virus transmitted by Aedes aegypti mosquitoes is still a problem for the people of Indonesia as a whole. Control of vegetable insecticides is one of the efforts to reduce vector population. The purpose of this study was to determine the effectiveness of leaves and flowers of breadfruit plants (Artocarpus altilis) as anti electric mosquito in killing Aedes aegypti mosquitoes. Type of research used is quasi experiment. The population in this study was Aedes aegypti mosquito larvae of \pm 600 that kept until adulthood. The sample in this study was 270 Aedes aegypti adult mosquitoes. Analysis with the table against the average mortality of mosquitoes with 3 replication. The results of this study showed that $300 \mathrm{mg}$ dye bran powder mat was effective after 30 minutes of observation with the number of Aedes aegypti mosquitoes that died on average reaching 16 tails (53\%) in three repetitions. While on the powder flower dose of $300 \mathrm{mg}$ dye is said to be more effective after 25 minutes of observation reach Lethal Dosage 50 (LD50) with the number of dead mosquitoes reaching 16 average (53\%) and also at 30 minutes observation Lethal Dose 50 (LD50) Where the dead mosquitoes averaged 20 (67\%) with three repetitions each. Conclusions obtained with the same dose of $300 \mathrm{mg}$ dose with observation time of 30 minutes mat powder flower powder is more effective than the powder mat leaf powder. It is recommended that entrepreneurs make anti-mosquito electrically with the active ingredients of powder flower powder to be more environmentally friendly.
\end{abstract}

Keywords: DHF, Leaves, Breadfruit flower, Aedes aegypti

\section{ABSTRAK}

DBD adalah penyakit yang disebabkan virus dengue yang ditularkan oleh nyamuk Aedes aegypti masih menjadi masalah bagi masyarakat Indonesia secara keseluruhan. Pengendalian insektisida nabati merupakan salah satu upaya untuk mengurangi populasi vektor.Tujuan penelitian ini adalah untuk mengetahui efektivitas daun dan bunga tanaman sukun (Artocarpus altilis) sebagai anti nyamuk mat elektrik dalam membunuh nyamuk Aedes aegypti. Jenis penelitian yang digunakan adalah eksperimen semu. Populasi dalam penelitian ini jentik nyamuk Aedes aegypti sejumlah \pm 600 yang dipelihara sampai dewasa. Sampel dalam penelitian ini adalah 270 ekor nyamuk Aedes aegypti dewasa. Analisa dengan tabel terhadap rata - rata kematian nyamuk dengan 3 kali replikasi. Hasil penelitian ini menunjukkan bahwa mat serbuk daun sukun dosis $300 \mathrm{mg}$ diinyatakan efektif setelah 30 menit pengamatan dengan jumlah nyamuk Aedes aegypti yang mati rata - rata mencapai 16 ekor (53\%) dalam tiga kali pengulangan. Sedangkan pada mat serbuk bunga sukun dosis $300 \mathrm{mg}$ diinyatakan lebih efektif setelah 25 menit pengamatan mencapai Lethal Dosis $50\left(L_{50}\right)$ dengan jumlah nyamuk yang mati rata -rata mencapai 16 ekor (53\%) dan juga pada 30 menit pengamatan Lethal Dosis $50\left(\mathrm{LD}_{50}\right)$ dimana nyamuk yang mati rata - rata mencapai 20 ekor $(67 \%)$ dengan masing - masing tiga kali pengulangan. Kesimpulan yang didapatkan dengan dosis yang sama yaitu dosis $300 \mathrm{mg}$ dengan waktu pengamatan 30 menit mat serbuk bunga sukun lebih efektif dibandingkan dengan mat serbuk daun sukun. Disarankan agar pengusaha membuat anti nyamuk elektrik dengan bahan aktif mat serbuk bunga sukun agar lebih ramah lingkungan.

Kata Kunci : DBD, Daun Sukun, Bunga Sukun, Aedes aegypti.

\section{PENDAHULUAN}

$\mathrm{Di}$ Indonesia penyakit ditularkan serangga masih merupakan masalah dalam kesehatan masyarakat adalah malaria, demam berdarah, filariasis, dan pes. Meningkatnya populasi beberapa serangga menimbulkan masalah di berbagai sektor. Di sektor pertanian misalnya, beberapa serangga seperti belalang, wereng, ulat, merupakan hama yang merusak tanaman di pertanian rakyat dan mengakibatkan kerugian yang tidak sedikit adapun di sektor kesehatan, beberapa penyakit yang ditularkan melalui serangga sebagai vektor masih terus mewabah, seperti malaria, DHF, filariasis, ataupun pes. Dengan demikian, pengendalian serangga mutlak diperlukan baik untuk memberantas hama tanaman, maupun untuk menurunkan insiden penyakit yang ditularkan oleh vektor (Sumantri, 2015).

Penyakit DBD yang dibawa oleh nyamuk Aedes aegypti sampai saat ini masih tetap menjadi masalah bagi masyarakat Indonesia secara keseluruhan. Selain menyebabkan kesakitan dan kematian, penyakit DBD juga dapat menimbulkan masalah sosial dan ekonomi bagi masyarakat. Kerugian sosial yang terjadi antara lain dapat menimbulkan kepanikan dalam keluarga dan berkurangnya usia harapan hidup (WHO, 2005).

Sejak pertama kali kasus DBD di laporkan di Indonesia tahun 1968 di Jakarta dan Surabaya, angka kesakitan dan penyebaran penyakit DBD semakin meluas. 
Jurnal Sulolipu : Media Komunikasi Sivitas Akademika dan Masyarakat

Vol. 17 No.II 2017

e-issn : 2622-6960, p-issn : 0854-624X

Penyakit ini endemis di semua provinsi, dan seringkali menimbulkan kejadian luar biasa (KLB) di beberapa Kabupaten dan Kota di Indonesia. Tahun 2014 kasus DBD menyerang 424 Kabupaten atau Kota di Indonesia dengan penderita sebanyak 99.938 orang dan kematian sebanyak 907 orang ( Suwito et al., 2015).

Pengendalian adalah salah satu upaya untuk menurunkan atau menekan populasi vektor. Pengendalian vektor penyakit dengan penggunaan insektisida untuk membunuh nyamuk dewasa, penggunaan abate sebagai larvasida, dan repellent untuk mencegah gigitan nyamuk. Penggunaan insektisida organik sintetik sayangnya tidak disertai dengan perhatian terhadap efek samping yang bisa terjadi. Penggunaan dosis yang subletal merangsang terjadinya adaptasi diri serangga terhadap insektisida. Sifat ini akan diturunkan ke generasi berikutnya, sehingga timbul populasi baru yang resisten terhadap suatu jenis insektisida (Sembel, 2010).

Insektisida yang mengandung bahan kimia berbahaya seperti penggunaan organoklorin telah dilarang penggunaanya di Indonesia. Penggunaan insektisida kimia dalam waktu lama dan pemberian dosis yang berlebih akan mengakibatkan resisten terhadap organisme target (WHO, 2005).

Vektor penyakit merupakan Arthropoda yang dapat menularkan, memindahkan dan menjadi sumber penular penyakit terhadap manusia (Kemenkes, 2010). Dengue Haemorragic Fever adalah penyakit endemis yang disebabkan oleh virus di daerah tropis dan subtropis yang kadang-kadang menjadi endemik. Virus penyakit ini membutuhkan masa multiplikasi selama 8-10 hari sebelum nyamuk menjadi infektif. Penyakit ini khususnya ditularkan oleh nyamuk spesies Aedes, terutama Aedes aegypti. Penyakit ini merupakan penyakit endemis di Indonesia dan terjadi sepanjang tahun terutama pada saat musim penghujan (Sumantri , 2015).

Mengingat dampak negatif yang dapat terjadi, maka perlu digunakaan alternatif lain. Penggunaan insektisida nabati merupakan salah satu alternatif yang dapat dilakukan, sebab insektisida nabati lebih aman karena residunya mudah hilang, dan mudah terurai (biodegradable) sehingga tidak mencemari lingkungan (Kardinan, 2004).

Tanaman sukun (Artocarpus altilis) adalah salah satu tanaman yang memiliki kandungan senyawa insektisida seperti senyawa saponin, tanin, dan flavonoid yang mempunyai dampak terhadap serangga,yang berpotensi digunakan sebagai insektisida nabati. Tanaman sukun (Artocarpus altilis) merupakan tanaman menahun yang banyak tumbuh di Indonesia dan sejak lama digunakan sebagai obat tradisional. Selain pohonnya sebagai perindang, buahnya yang telah tua dikenal sebagai sumber karbohidrat untuk bahan makanan.

Daun dan bunga sukun setelah dikeringkan secara tradisional digunakan sebagai pengusir nyamuk dengan cara dibakar seperti obat nyamuk bakar.

Penelitian yang dilakukan sebelumnya oleh Edi et al., (2011), membuktikan bahwa bunga sukun mampu melumpuhkan 10 ekor nyamuk dengan rata- rata waktu yang digunakan 15,6 menit selama 5 kali pengulangan. Dalam penelitian oleh Lumowa (2013) bahwa serbuk bunga sukun (Artocarpus altilis L) yang berfungsi sebagai isi ulang anti nyamuk elektrik dengan kadar 2 gram bunga sukun mampu membunuh paling banyak nyamuk dengan rata rata 15,6 ekor nyamuk (78 $\%$ ). Menurut hasil penelitian Sitorus et al., (2013) menunjukkan bahwa pada berat $300 \mathrm{mg}$ sudah terdapat kematian $50 \%$ lebih (9 ekor nyamuk mati) setelah pengamatan 30 menit yang berarti tercapai Lethal Dose (LD50), dan rata-rata kematian nyamuk Aedes, spp sebanyak 8 ekor nyamuk mati.

Daun dan bunga tanaman sukun (Artocarpus altilis) inilah yang menarik untuk dibahas dalam sebuah penelitian skripsi dengan membandingkan kemampuan dua bagian tanaman sukun sebagai insektisida nabati dalam mengendalikan nyamuk Aedes aegypti.

adalah:

Adapun tujuan dalam penelitian ini

1. Tujuan Umum

Untuk mengetahui efektivitas daun dan bunga tanaman sukun (Artocarpus altilis) sebagai anti nyamuk mat elektrik dalam membunuh nyamuk Aedes aegypti".

2. Tujuan Khusus

a. Untuk mengetahui efektivitas mat serbuk daun sukun dosis $300 \mathrm{mg}$ dalam membunuh nyamuk Aedes aegypti.

b. Untuk mengetahui efektivitas mat serbuk bunga sukun dosis $300 \mathrm{mg}$ 
dalam membunuh nyamuk Aedes aegypti.

\section{BAHAN DAN METODE}

\section{Jenis Penelitian}

Adapun jenis penelitian yang digunakan adalah eksperimen semu (Quasi eksperimental) yaitu untuk mengetahui efektivitas daun dan bunga tanaman sukun (Artocarpus altilis) dosis $300 \mathrm{mg}$ dalam interval waktu 5 menit pemaparan selama 30 menit perlakuan, jumlah nyamuk Aedes aegypti masing - masing 30 ekor dengan 3 kali replikasi sebagai anti nyamuk mat elektrik dalam membunuh nyamuk.

\section{Lokasi dan Waktu Penelitian}

\section{a. Lokasi Penelitian}

Lokasi penelitian dilaksanakan di Ruangan Workshop Kampus Jurusan Kesehatan Lingkungan Politeknik Kesehatan Makassar, pembuatan mat serbuk daun sukun dan bunga sukun di lakukan di Jl. Rappocini Lorong 6 No. 42 dan Laboratorium Jurusan Kesehatan Lingkungan Politeknik Kesehatan Makassar.

b. Lokasi Pengambilan Sampel

Pengambilan sampel daun sukun dan bunga sukun di Desa Watutoa, Kabupaten Soppeng dan lokasi pengambilan sampel larva nyamuk Aedes aegypti di Jalan Nuri.

\section{Waktu penelitian}

a. Tahapan persiapan, pada tahap ini meliputi kegiatan seminar proposal dilaksanakan pada bulan januari 2017.

b. Tahapan penelitian, pada tahap pelaksanaan penelitian meliputi pengolahan dan pengumpulan data bahan yang kemudian ujian hasil yang dilaksanakan pada bulan Maret - Juni 2017.

\section{Variabel Penelitian}

a. Variabel bebas adalah variabel yang mempengaruhi variabel terikat yaitu Mat serbuk daun sukun dan bunga sukun 300 $\mathrm{mg}$ dalam interval waktu 5 menit pemaparan selama 30 menit pada kotak percobaan jumlah nyamuk Aedes aegypti masing - masing 30 ekor dengan 3 kali replikasi.

b. Variabel terikat adalah variabel yang dipengaruhi oleh variabel bebas yaitu keefektifan dalam membunuh nyamuk Aedes aegypti.

c. Variabel penganggu adalah variabel yang di duga turut mempengaruhi variabel terikat adalah Suhu, kelembaban, dan waktu.

\section{Definisi Operasional dan Kriteria Objektif}

i. Daun sukun dalam penelitian ini adalah daun sukun yang sudah tua, berwarna kecoklat - coklatan yang diambil lalu dijemur sampai kering, kemudian ditumbuk sampai halus lalu di bentuk mat serbuk daun yang dipasang pada kotak percobaan.

ii. Bunga sukun dalam penelitian ini adalah bunga sukun jantan yang sudah tua, berwarna kecoklat-coklatan, jatuh kepermukaan tanah yang diambil lalu dijemur sampai kering, kemudian ditumbuk sampai halus lalu di bentuk mat serbuk daun yang dipasang pada kotak percobaan.

iii. Keefektifan dalam membunuh nyamuk Aedes aegypti adalah hasil pengamatan pada saat melakukan pengujian nyamuk dengan mat serbuk daun dan bunga tanaman sukun (Artocarpus altilis) yang diukur dengan jumlah nyamuk yang mati pada setiap kotak percobaan.

Kriteria Objektif:

1) Pengujian bahan aktif mat serbuk daun tanaman sukun (Artocarpus altilis) dengan dosis yang sama 300 mg dalam interval waktu 5 menit pemaparan selama 30 menit , masing - masing 30 ekor nyamuk yang berada di dalam kotak percobaan dengan 3 kali replikasi, diinyatakan lebih efektif apabila rata - rata hasil pengamatan menunjukkan nyamuk yang mati dalam jumlah yang lebih besar dan mencapai LD50.

2) Pengujian bahan aktif mat serbuk daun dan bunga tanaman sukun (Artocarpus altilis) dengan dosis yang sama $300 \mathrm{mg}$ dalam interval waktu 5 menit pemaparan selama 30 menit, masing-masing 30 ekor nyamuk yang berada di dalam kotak 
percobaan dengan 3 kali replikasi, diinyatakan tidak efektif apabila rata - rata hasil pengamatan menunjukkan nyamuk yang mati dalam jumlah yang lebih kecil dan tidak mencapai LD 50 .

iv. Suhu adalah suhu udara pada ruang kotak percobaan yang diukur dengan alat termometer dengan satuan ukur ${ }^{\circ} \mathrm{C}$.

v. Kelembaban dalam penelitian ini adalah kondisi suhu pada ruang kotak percobaan yang diukur dengan alat hygrotermometer dengan satuan \%.

vi. Waktu dalam penelitian ini adalah waktu kontak mat serbuk daun dan bunga tanaman sukun (Artocarpus altilis) dengan jumlah 30 ekor nyamuk Aedes aegypti pada setiap kotak percobaan dalam interval waktu 5 menit pemaparan selama 30 menit dengan 3 kali replikasi di ruangan yang diukur dengan alat stopwatch dengan satuan ukur s.

vii. $\mathrm{LD}_{50}$ adalah dosis yang menyebabkan kematian $50 \%$ nyamuk Aedes aegypti pada pemajanan selama waktu yang ditentukan.

\section{Populasi dan Sampel}

\section{a. Populasi}

Populasi dalam penelitian ini adalah larva nyamuk Aedes aegypti instar III sejumlah \pm 600 yang dipelihara sampai dewasa yang diambil dari kotak pemeliharaan dan dimasukkan kedalam kotak perlakuan.

b. Sampel

Sampel dalam penelitian ini adalah 270 ekor nyamuk Aedes aegypti dewasa.

\section{Analisa Data}

Analisa dengan tabel terhadap rata - rata kematian nyamuk dengan dosis mat serbuk daun dan bunga tanaman sukun (Artocarpus altilis) dosis yang sama,waktu yang sama dengan 3 kali replikasi.

\section{HASIL PENELITIAN}

Hasil penelitian dengan menggunakan perbandingan antara daun dan bunga sukun (Artocarpus altilis) dengan dosis sama yaitu 300 mg, yang dipaparkan pada nyamuk Aedes aegypti, selama 30 menit dan diamati setiap interval 5 menit dimana setiap ruangan percobaan seluas $60 \times 60 \times 60 \mathrm{~cm}^{2}$, dengan masing- masing jumlah 30 ekor nyamuk dan juga kontrol yang berisi 30 ekor nyamuk Aedes aegypti.

Sesuai dengan pernyataan di atas maka hasil penelitian dapat dilihat pada tabel sebagai berikut:

1. Hasil pengamatan nyamuk Aedes aegypti yang mati (Kontrol)

Hasil pengamatan yang telah dilakukan pada kontrol dengan waktu pengamatan setiap interval 5 menit selama 30 menit yang dilakukan sebanyak tiga kali replikasi, tidak terdapat nyamuk yang mati.

Hal ini membuktikan bahwa kondisi lingkungan nyamuk yang terdapat dalam kotak percobaan tidak mempengaruhi kelangsungan hidup nyamuk tersebut sehingga nyamuk Aedes aegypti yang ada di ruang kotak percobaan menunjukkan hasil yang sama tidak terjadi perbedaan atau kematian selama 30 menit pengamatan. Pada kontrol tersebut tidak dipaparkan dengan daun dan bunga sukun (Artocarpus altilis) namun diberikan perlakuan dengan memasukkan 30 ekor nyamuk Aedes aegypti kedalam kotak percobaan.

2. Hasil pengamatan nyamuk Aedes aegypti yang mati setelah pemajanan dosis $\mathbf{3 0 0}$ mg mat serbuk daun sukun (Artocarpus altilis).

Tabel 1

Hasil Pengamatan Nyamuk Aedes aegypti

Yang Mati Setelah Pemajanan Dosis 300 Mg Mat Serbuk Daun Sukun Setiap 5 Menit Pengamatan Selama 30 Menit

\begin{tabular}{|c|c|c|c|c|c|}
\hline \multicolumn{6}{|c|}{ Jumlah nyamuk Aedes aegypti yang mati } \\
\hline \multirow{2}{*}{$\begin{array}{l}\text { Waktu } \\
\text { pengamatan }\end{array}$} & \multicolumn{3}{|c|}{ Ulangan } & \multirow{2}{*}{$\begin{array}{l}\text { Rata - } \\
\text { rata }\end{array}$} & \\
\hline & I & II & III & & \\
\hline & Mati & Mati & Mati & Mati & \\
\hline 5 menit & - & - & - & - & \\
\hline 10 menit & 2 & 3 & 2 & & 2 \\
\hline 15 menit & 4 & 4 & 5 & & 4 \\
\hline 20 menit & 7 & 6 & 6 & & 6 \\
\hline 25 menit & 12 & 11 & 10 & & 11 \\
\hline 30 menit & 16 & 18 & 16 & & 16 \\
\hline
\end{tabular}

Sumber : Data Primer

Berdasarkan tabel 1 dapat dilihat bahwa pada pemajanan dosis $300 \mathrm{mg}$ mat serbuk daun sukun dengan waktu pengamatan selama 5 menit rata - rata Nyamuk Aedes aegypti masih bertahan hidup di dalam ruang kotak percobaan, pengamatan 10 menit rata - rata 
nyamuk yang mati sebanyak 2 ekor, pengamatan 15 menit rata - rata nyamuk yang mati sebanyak 4 ekor, pengamatan 20 menit rata - rata nyamuk yang mati sebanyak 6 ekor, pengamatan 25 menit rata - rata nyamuk yang mati sebanyak 11 ekor, dan pengamatan 30 menit rata - rata nyamuk yang mati sebanyak 16 ekor.

3. Hasil pengamatan nyamuk Aedes aegypti yang mati setelah pemajanan dosis 300 mg mat serbuk bunga sukun (Artocarpus altilis)

Tabel 2

Hasil Pengamatan Nyamuk Aedes aegypti

Yang Mati Setelah Pemajanan Dosis $300 \mathrm{Mg}$ Mat Serbuk Daun Sukun Setiap 5 Menit Pengamatan Selama 30 Menit

\begin{tabular}{|c|c|c|c|c|}
\hline \multicolumn{5}{|c|}{ Jumlah nyamuk Aedes aegypti yang mati } \\
\hline \multirow{3}{*}{$\begin{array}{l}\text { Waktu } \\
\text { pengamatan }\end{array}$} & \multicolumn{3}{|c|}{ Ulangan } & \multirow{2}{*}{ Rata - rata } \\
\hline & I & II & III & \\
\hline & Mati & Mati & Mati & Mati \\
\hline 5 menit & - & - & - & - \\
\hline 10 menit & 5 & 4 & 6 & 5 \\
\hline 15 menit & 8 & 9 & 7 & 8 \\
\hline 20 menit & 11 & 11 & 12 & 11 \\
\hline 25 menit & 15 & 16 & 18 & 16 \\
\hline 30 menit & 20 & 19 & 21 & 20 \\
\hline
\end{tabular}

Sumber : Data Primer

Berdasarkan tabel 2 dapat dilihat bahwa pada pemajanan dosis $300 \mathrm{mg}$ ekstrak bunga sukun dengan waktu pengamatan selama 5 menit rata - rata Nyamuk Aedes aegypti masih bertahan hidup di dalam ruang kotak percobaan, pengamatan 10 menit rata rata nyamuk yang mati sebanyak 5 ekor, pengamatan 15 menit rata - rata nyamuk yang mati sebanyak 8 ekor, pengamatan 20 menit rata - rata nyamuk yang mati sebanyak 11 ekor, pengamatan 25 menit rata - rata nyamuk yang mati sebanyak 16 ekor, dan pengamatan 30 menit rata - rata nyamuk yang mati 20 ekor.

\section{Suhu dan kelembaban udara di ruang penelitian}

Pada saat penelitian dilakukan, pengukuran suhu udara di ruang kotak percobaan dengan mengunakan termometer diperoleh hasil pengukuran yakni untuk replikasi I adalah $26,2^{\circ} \mathrm{C}$, replikasi II adalah $27,8^{\circ} \mathrm{C}$, replikasi III adalah $27,3^{\circ} \mathrm{C}$ jadi rata - rata suhu ruangan penelitian adalah 27,1 ${ }^{\circ} \mathrm{C}$. Pada saat penelitian dilakukan, kelembaban udara di ruangan penelitian di ukur dengan mengunakan hygrotermometer dengan hasil pengukuran kelembaban untuk replikasi I sebesar $65 \%$, pada replikasi II sebesar $72 \%$, pada replikasi III sebesar 72 $\%$, jadi rata-rata kelembaban ruangan penelitian tersebut yaitu sekitar $69.6 \%$.

\section{PEMBAHASAN}

Hasil penelitian dengan mengunakan daun dan bunga sukun (Artocarpus altilis) dengan dosis sama yaitu $300 \mathrm{mg}$ dengan perlakuan kontrol yang dilakukan pengulangan sebanyak tiga kali selama 30 menit pengamatan dengan interval setiap waktu 5 menit. Diperoleh jumlah Nyamuk Aedes aegypti yang mati pada waktu pemaparan tertentu. Pada kontrol terlihat bahwa tidak dijumpai adanya Nyamuk Aedes aegypti yang mati. Hal ini membuktikan bahwa kondisi lingkungan nyamuk yang terdapat dalam ruang kotak percobaan mendukung kelangsungan hidup nyamuk tersebut.

1. Kemampuan mat serbuk daun sukun dosis $300 \mathrm{mg}$ sebagai anti Nyamuk elektrik dalam membunuh nyamuk Aedes aegypti

Pada pemajanan dosis $300 \mathrm{mg}$ mat
serbuk daun sukun dengan waktu pengamatan selama 5 menit pertama semua nyamuk Aedes aegypti rata - rata masih bertahan hidup dan terbang menepi ke pinggir di dalam ruang kotak percobaan, setelah 10 menit rata - rata nyamuk yang mati sebanyak 2 ekor menunjukkan bahwa di dalam ruang kotak percobaan terdapat aroma menyengat dari proses pemanasan, pada 15 menit rata - rata nyamuk yang mati mencapai 4 ekor karena aroma yang dikeluarkan semakin menyengat pada ruang kotak percobaan yang menyebabkan nyamuk mati satu persatu, begitupun pada 20 menit rata - rata nyamuk yang mati mencapai 6 ekor, pada 25 menit rata - rata nyamuk yang mati mencapai 11 ekor, Setelah 30 menit pengamatan mencapai Lethal Dosis 50 (LD50) dimana nyamuk yang mati rata - rata mencapai 16 ekor (53\%) 
dengan tiga kali pengulangan, Hal ini berarti bahwa lama waktu kontak berpengaruh terhadap kematian nyamuk Aedes aegypti, dimana semakin lama waktu kontak nyamuk terhadap mat serbuk daun sukun semakin mempengaruhi jumlah kematian nyamuk sehingga mat serbuk daun sukun dosis 300 mg diinyatakan efektif sebagai anti nyamuk elektrik dalam membunuh nyamuk Aedes aegypti.

Hal ini disebabkan oleh kandungan senyawa kimia yang terdapat pada daun sukun yaitu saponin, flavonoid dan tanin yang berfungsi sebagai insektisida yang dapat membunuh nyamuk Aedes aegypti. Saponin memiliki aktivitas insektisida yang jelas, saponin bekerja dengan tepat dan cepat terhadap serangga. Efek yang paling sering diamati adalah menyebabkan kematian, flavonoid berfungsi sebagai racun pernapasan atau inhibitor pernapasan sehingga saat nyamuk Aedes melakukan pernapasan flavonoid akan masuk bersama udara $\left(\mathrm{O}_{2}\right)$ melalui alat pernapasannya (Lumowa, 2013) dan Tanin bersifat anti bakteri dan anti virus. Mekanisme kerja tanin akan merusak membran sel bakteri dan mengerutkan dinding sel sehingga akan mengganggu permeabilitas sel bakteri, hingga pertumbuhan sel bakteri terlambat dan bahkan akan mati. Sebagai anti virus, tanin akan merusak enzim yang diperlukan virus untuk memperbanyak diri, hal ini yang mengakibatkan virus sulit berkembang (Shabella, 2012).

Menurut cara kerjanya, daun sukun juga dapat digolongkan sebagai insektisida racun saraf karena berdasarkan pengamatan yang dilakukan selama percobaan, nyamuk Aedes aegypti mengalami perubahan sebelum dan sesudah dinyalakan anti nyamuk mat elektrik daun sukun. Nyamuk Aedes aegypti dari yang bergerak sangat aktif berusaha keluar karena aroma yang dikeluarkan mat serbuk daun sukun sampai pada akhirnya menjadi lamban, lemas, lumpuh dan kemudian mati (Sitorus et al., 2013).

Hal ini sejalan dengan penelitian yang dilakukan oleh Sitorus et al., (2013) menunjukkan bahwa pada variabel kontrol selama 30 menit pengamatan dengan 3 kali pengulangan tidak ditemukan nyamuk Aedes spp mati, berat efektif mat daun sukun (Artocarpus altilis) sebagai mat elektrik dalam membunuh nyamuk Aedes, spp adalah berat mat $300 \mathrm{mg}$ dengan waktu pemaparan 30 menit dengan tingkat kematian nyamuk Aedes, spp sebesar $53,33 \%$ (lebih dari setengah populasi nyamuk Aedes, spp mati.

Pada penelitian tersebut dengan konsentrasi yang berbeda diinyatakan mampu membunuh nyamuk Aedes, spp dengan berat mat serbuk daun sukun 300 mg dengan waktu pemaparan 30 menit sedangkan dalam penelitian ini mat serbuk daun sukun $300 \mathrm{mg}$ setelah 30 menit pengamatan mencapai Lethal Dosis 50 (LD50) dimana nyamuk yang mati rata - rata mencapai 16 ekor (53\%) dengan tiga kali pengulangan, perbedaan secara signifikan dari penelitian yaitu dalam penelitian ini bertujuan untuk mengetahui efektivitas perbandingan antara daun dan bunga tanaman sukun (Artocarpus altilis), dengan dosis dan waktu pengamatan yang sama menunjukkan hasil yang tidak jauh berbeda sehingga dapat diinyatakan bahwa mat serbuk daun sukun efektif dengan dosis 300 mg.

2. Kemampuan mat serbuk bunga sukun dosis $300 \mathrm{mg}$ sebagai anti Nyamuk elektrik dalam membunuh nyamuk Aedes aegypti

Pada pemajanan dosis $300 \mathrm{mg}$ mat serbuk bunga sukun dengan waktu pengamatan selama 5 menit pertama semua nyamuk Aedes aegypti rata - rata masih bertahan hidup dan terbang menepi ke pinggir di dalam ruang kotak percobaan, setelah 10 menit rata - rata nyamuk yang mati sebanyak 5 ekor, pada 15 menit rata rata nyamuk yang mati mencapai 8 ekor, pada 20 menit rata - rata nyamuk yang mati mencapai 11 ekor, Setelah 25 menit pengamatan untuk memenuhi Lethal Dosis 50 (LD ${ }_{50}$ ) dimana nyamuk yang mati rata rata mencapai 16 ekor (53\%) dan juga pada 30 menit pengamatan untuk memenuhi Lethal Dosis $50\left(\mathrm{LD}_{50}\right)$ dimana nyamuk yang mati rata - rata mencapai 20 ekor $(67 \%)$ dengan masing - masing tiga kali pengulangan. Adanya perbedaan jumlah kematian nyamuk berdasarkan interval waktu pengamatan hal ini menunjukkan bahwa lama waktu kontak berpengaruh terhadap kematian nyamuk Aedes aegypti, 
dimana semakin lama waktu kontak nyamuk terhadap mat serbuk bunga sukun semakin mempengaruhi jumlah kematian nyamuk sehingga mat serbuk bunga sukun dosis $300 \mathrm{mg}$ sebagai anti Nyamuk elektrik diinyatakan sangat efektif dalam membunuh nyamuk Aedes aegypti.

Kematian nyamuk Aedes aegypti disebabkan karena zat - zat aktif yang terdapat pada bunga sukun yaitu saponin, tanin, dan flavonoid senyawa - senyawa tersebut yang berperan penting dalam proses penguapan mat serbuk bunga sukun yang memiliki fungsi sebagai insetisida nabati. Kematian nyamuk disebabkan karena keracunan oleh zat - zat aktif yang ada pada bunga sukun akibat aroma yang dikeluarkan oleh mat serbuk bunga sukun dimana aroma tersebut menyengat dan menyebar keseluruh ruangan kotak percobaan hingga nyamuk Aedes aegypti yang ada di ruang kotak percobaan tidak mampu lagi bertahan hidup.

Saponin merupakan kandungan yang terdapat pada bunga sukun yang dapat menyerang sistem saraf nyamuk. Flavonoid merupakan salah satu kandungan yang terdapat pada bunga sukun jantan (Artocarpus altilis L.) yang berfungsi sebagai anticholinesterase. Anticholinesterase menyebabkan enzim cholinesterase mengalami fosforilasi dan menjadi tidak aktif. Dengan tidak aktifnya enzim cholinesterase maka akan menyebabkan terjadi hambatan proses degradasi asetilkolin sehingga terjadi akumulasi asetilkolin di celah sinap. Selanjutnya terjadi peningkatan transmisi rangsang, yang menyebabkan otot pernapasan mengalami kontraksi secara terus-menerus sehingga terjadi kejang otot pernapasan dan menyebabkan kematian nyamuk dan tanin memiliki mekanisme kerja dalam menghambat atau bahkan membunuh nyamuk.

Terdapat perbedaan jumlah zat aktif pada masing - masing kadar bunga sukun sehingga menyebabkan adanya perbedaan jumlah zat aktif yang masuk kedalam sistem pernapasan nyamuk yang di uji coba saat elektrik dinyalakan. Kematian nyamuk Aedes aegypti disebabkan karena keracunan saat mesin elektrik dinyalakan. Pada saat mesin elektrik dinyalakan akan terjadi evaporasi terhadap kandungan zat zat aktif yang ada di dalam bunga sukun yang mengeluarkan aroma yang tidak disukai oleh nyamuk dan dapat menyerang sistem pernapasan nyamuk. Sedangkan ditinjau dari segi waktu lamanya pemajanan bahwa semakin lama waktu pemajanannya jumlah nyamuk yang mati semakin banyak .

Hal ini sejalan dengan penelitian yang dilakukan sebelumnya oleh Edi et al., (2011), membuktikan bahwa mat bunga sukun dapat mengusir nyamuk. Dengan dosis 6 gram mat bunga sukun lebih cepat mengusir nyamuk dibandingkan dengan mat sintesis. bunga sukun mampu melumpuhkan 10 ekor nyamuk dengan rata- rata waktu yang digunakan 15,6 menit selama 5 kali pengulangan dan dalam penelitian oleh Lumowa (2013) bahwa serbuk bunga sukun (Artocarpus altilis $L$ ) yang berfungsi sebagai isi ulang anti nyamuk elektrik dengan kadar 2 gram bunga sukun mampu membunuh paling banyak nyamuk dengan rata rata 15,6 ekor nyamuk (78\%).

Pada penelitian tersebut dengan tujuan yang berbeda dimana dosis 6 gram mat bunga sukun lebih cepat mengusir nyamuk dibandingkan dengan mat sintesis dan kadar 2 gram bunga sukun mampu membunuh paling banyak nyamuk dengan rata rata 15,6 ekor nyamuk (78 \%) sedangkan pada penelitian ini mat bunga sukun diinyatakan lebih efektif dibandingkan dengan mat daun sukun dosis $300 \mathrm{mg}$ dengan waktu pengamatan selama 30 menit pada dasarnya penentuan dosis $300 \mathrm{mg}$ pada mat bunga sukun ini mengacu pada penelitian mat daun sukun karena untuk melakukan suatu pengujian dalam hal ini untuk membandingkan antara daun dan bunga tanaman sukun (Artocarpus altilis) harus mengunakan perlakuan yang sama dan jika dibandingkan dengan penelitian sebelumnya ini menunjukkan bahwa kadar yang digunakan lebih tinggi mampu dalam membunuh nyamuk dan pada penelitian ini mengunakan kadar lebih rendah namun juga lebih efektif.

Hasil penelitian menunjukan bahwa pada dosis $300 \mathrm{mg}$ untuk mat serbuk daun dan bunga sukun (Artocarpus altilis). Mat serbuk bunga sukun diinyatakan lebih efektif dibandingkan dengan daun sukun dimana Lethal Dosis $50\left(\mathrm{LD}_{50}\right)$ telah dicapai setelah 
25 menit pengamatan dengan jumlah nyamuk yang mati rata -rata mencapai 16 ekor (53 \%) dan juga pada 30 menit pengamatan Lethal Dosis 50 (LD50) dimana nyamuk yang mati rata - rata mencapai 20 ekor $(67 \%)$ dengan masing - masing tiga kali pengulangan sedangkan untuk daun sukun Lethal Dosis 50 (LD50) baru dicapai setelah 30 menit pengamatan dengan jumlah nyamuk Aedes aegypti yang mati rata -rata mencapai 16 ekor (53\%) dalam tiga kali pengulangan.

Dalam penelitian Sitorus et al., 2013 menyatakan bahwa perbandingan kadar air yang tidak sesuai dapat mempengaruhi penguapan aroma daun sukun. Jika kadar air terlalu sedikit, maka serbuk tidak terkena air secara menyeluruh. Selain itu bunga sukun memiliki zat - zat aktif yang terkandung di dalamnya seperti saponin, flavonoid, dan tanin yang tidak disukai dan sangat dihindari serangga, berfungsi sebagai insektisida yang dapat menyerang sistem pernapasan nyamuk Aedes aegypti. Zat- zat inilah yang akan mempengaruhi nyamuk sehingga dapat menyebabkan kematian dengan mengunakan metode elektrik, dimana metode elektrik akan berdampak langsung pada pernapasan nyamuk. Pada proses pembuatan mat serbuk bunga sukun, zat aktif yang terdapat pada mat tidak dapat diketahui secara pasti seberapa besar kandungannya namun diyakini bahwa zat aktif tersebut yang berperan penting dalam mekanisme insektisida mat serbuk bunga sukun.

Perlakuan pada kontrol tidak terdapat nyamuk yang mati, sehingga hasil yang diperoleh dapat mengambarkan hasil yang sebenarnya dan terdapat perbedaan antara perlakuan jumlah kematian nyamuk dengan menggunakan mat serbuk bunga sukun dan daun sukun. Salahsatu faktor yang kemungkinan mempengaruhi jumlah kematian nyamuk disebabkan karena mat serbuk bunga sukun yang lebih halus tanpa serat - serat sehingga kadar air lebih mudah larut pada mat serbuk bunga sukun dan dapat mempengaruhi bentuk kepadatan mat.

Perbedaan efektivitas dari mat serbuk daun dan bunga tanaman sukun (Artocarpus altilis) berdasarkan pengamatan bahwa dari daun dan bunga tanaman sukun
(Artocarpus altilis) mengandung bahan aktif yang sama namun memiliki perbedaan dalam mencapai $\mathrm{LD}_{50}$ hal ini kemungkinan dipengaruhi oleh mekanisme kerja dari bahan - bahan aktif yang terdapat pada kedua bagian tersebut. Dimana bunga sukun mekanisme kerjanya lebih cepat dalam membunuh nyamuk Aedes aegypti dengan menggunakan metode elektrik maka secara tidak langsung akan terjadi proses pemanasan saat mesin anti nyamuk elektrik diinyalakan pada bunga sukun baunya lebih menyengat sehingga aroma yang dikeluarkan itulah yang tidak disukai oleh nyamuk yang akan berdampak langsung pada sistem pernapasan nyamuk. Mekanisme kerja dari bunga sukun lebih cepat dibandingkan dengan daun sukun Insektisida nabati mempunyai kelompok metabolit sekunder yang mengandung beribu-ribu senyawa bioaktif seperti alkaloid, fenolik, dan zat kimia sekunder lainnya. Senyawa bioaktif yang terdapat pada tanaman dapat di manfaatkan seperti layaknya insektisida sintetik. Perbedaannya adalah bahan aktif pada insektisida nabati disintesa dari tumbuhan dan jenisnya bisa lebih dari satu macam (campuran). Bagian tumbuhan seperti daun, bunga, buah, biji, kulit dan batang dan sebagainya dapat digunakan dalam bentuk utuh, bubuk ataupun ekstraksi (dengan air ataupun pelarut organik). Insektisida nabati merupakan bahan alami, bersifat mudah terurai di alam (biodegradable) sehingga tidak mencemari lingkungan dan relatif aman bagi manusia maupun ternak karena residunya mudah hilang (Naria, 2005).

Cara pembuatan insektisida nabati dari berbagai jenis tumbuhan tidak dapat dijelaskan secara khusus atau distandarisasi karena memang sifatnya tidak berlaku secara umum. Pembuatan insektisida nabati dapat di lakukan secara sederhana atau secara laboratorium. Cara sederhana (jangka pendek) dapat di lakukan dengan penggunaan ekstrak sesegera mungkin setelah pembuatan ekstrak di lakukan.

Pada dasarnya penggunaan insektisida kimia dapat membahayakan kelangsungan hidup manusia, binatang dan mahluk hidup lainnya. Mengingat dampak negatif yang dapat terjadi, maka perlu digunakaan alternatif lain. Penggunaan 
insektisida nabati merupakan salah satu alternatif yang dapat dilakukan, sebab insektisida nabati lebih aman karena residunya mudah hilang, dan mudah terurai (biodegradable) sehingga tidak mencemari lingkungan (Kardinan, 2004).

Penggunaan mat serbuk bunga sukun sebagai anti nyamuk elektrik dalam membunuh nyamuk Aedes aegypti merupakan salahsatu alternatif yang paling efektif untuk mengurangi pencemaran lingkungan. Selain itu insektisida nabati hanya meninggalkan sedikit residu pada komponen lingkungan sehingga dianggap lebih aman daripada insektisida kimia, zat insektisida nabati lebih cepat terurai dialam sehingga tidak menyebabkan resistensi pada sasaran. Selain itu dapat dibuat sendiri dengan cara sederhana, satu bunga sukun yang dibentuk dapat menghasilkan lebih banyak mat, bahan mudah didapatkan disekitar rumah, dan lebih ekonomis.

Penggunaan insektisida nabati memiliki keunggulan dan kelemahan yaitu Insektisida nabati tidak atau hanya sedikit meninggalkan residu pada komponen lingkungan dan bahan makanan sehingga dianggap lebih aman dari pada insektisida sintetis/kimia, zat pestisidik dalam insektisida nabati lebih cepat terurai di alam sehingga tidak menimbulkan resistensi pada sasaran, dapat dibuat sendiri dengan cara yang sederhana, bahan membuat insektisida nabati dapat disediakan di sekitar rumah dan secara ekonomi tentunya akan mengurangi biaya pembelian insektisida.

Kelemahan dalam penggunaan insektisida nabati, selain keunggulan insektisida nabati, tentunya kita tidak dapat mengesampingkan beberapa kelemahan pemakaian insektisida nabati tersebut kelemahanya antara lain Insektisida nabati memiliki bahan aktif yang kompleks. (multiple activeingredient) dan kadang kala tidak dapat di deteksi, dan tanaman insektisida nabati yang sama, tetapi tumbuh di tempat yang berbeda, iklim berbeda, jenis tanah berbeda, umur tanaman berbeda, dan waktu panen yang berbeda mengakibatkan bahan aktifnya menjadi sangat bervariasi (Naria, 2005). Secara khusus kelemahan yang ada pada penelitian ini dimana mat yang dihasilkan belum dikemas dengan baik.
Nyamuk Aedes aegypti merupakan vektor yang dapat menularkan penyakit DBD (Demam Berdarah Dengue). Tata hidup Nyamuk Aedes aegypti hidup di dalam dan di sekitar rumah sehingga makanan yang diperoleh semuanya sudah tersedia disitu. Boleh dikatakan bahwa nyamuk betina sangat menyukai darah manusia (anthropophilic) daripada darah binatang. Kebiasaan menghisap darah terutama pada pagi hari jam 08.00 - 12.00 dan sore hari jam 15.00 - 17.00 (Soegijanto, 2006). Aedes aegypti suka beristirahat di tempat yang gelap, lembap, dan tersembunyi di dalam rumah atau bangunan, termasuk di kamar tidur, kamar mandi, kamar kecil, maupun di dapur. Nyamuk ini jarang ditemukan di luar rumah, di tumbuhan, atau di tempat terlindung lainnya. Di dalam ruangan, permukaan istirahat yang mereka suka adalah di bawah furnitur, benda yang tergantung seperti baju dan gorden, serta di dinding (WHO, 2005).

Nyamuk merupakan binatang berdarah dingin, proses - proses metabolisme dan siklus kehidupannya tergantung pada suhu lingkungan. Sehingga dalam penelitian ini terlebih dahulu dalam mendesain kotak percobaan dengan mempertimbangkan kebutuhan udara ruang kotak percobaan, maka pada setiap ruang dilengkapi dengan ventilasi $10 \%$ dari luas lantai permukaan kotak percobaan. Kemudian untuk mengetahui secara akurat suhu pada ruang kotak percobaan dilakukan pengukuran. Adapun hasil pengukuran suhu ruang penelitian, yang diukur selama melakukan penelitian diperoleh rata-rata suhu ruangan adalah $27,1{ }^{\circ} \mathrm{C}$ dengan kondisi suhu ruangan tersebut sesuai untuk kelangsungan kehidupan nyamuk sehingga tidak mempengaruhi perkembangan dan pertumbuhan nyamuk dikarenakan masih pada kisaran suhu optimal yang berkisar antara 25 - $35^{\circ} \mathrm{C}$. Suhu merupakan salahsatu faktor penting yang harus diperhatikan agar tidak mempengaruhi proses pengujian nyamuk terhadap mekanisme kerja dari bahan insektisida nabati.

Suhu ruang yang tinggi ataupun rendah akan mempengaruhi kelansungan hidup nyamuk yakni optimum pada suhu 25 - $35^{\circ} \mathrm{C}$ lama hidup nyamuk bila suhu selalu 
Jurnal Sulolipu : Media Komunikasi Sivitas Akademika dan Masyarakat

Vol. 17 No.II 2017

e-issn : 2622-6960, $p$-issn : 0854-624X

lebih dari 27 - $30{ }^{\circ} \mathrm{C}$, umur nyamuk akan menjadi lebih pendek (Sumantri, 2015).

Pada dasarnya kelembaban berbanding terbalik dengan suhu apabila suhu tinggi maka kelembaban rendah begitupun sebaliknya. Hasil pengukuran kelembaban udara dalam ruangan penelitian selama melakukan percobaan yaitu rata-rata kelembaban ruangan penelitian tersebut yaitu sekitar $69.6 \%$ Kelembaban juga merupakan salah satu kondisi lingkungan yang dapat mempengaruhi perkembangan nyamuk Aedes aegypti spiracle (lubang pada dinding tubuh nyamuk) yang terbuka lebar pada saat kelembaban rendah dan terjadi penguapan air dalam tubuh nyamuk yang menimbulkan keringnya cairan tubuh nyamuk.

Pada kelembaban kurang dari $60 \%$ umur nyamuk akan menjadi pendek, tidak bisa menjadi vektor, tidak cukup waktu untuk perpindahan virus dari lambung ke kelenjar ludah.

\section{PENUTUP}

1. Kesimpulan

a. Mat serbuk daun sukun dosis $300 \mathrm{mg}$ diinyatakan efektif setelah 30 menit mencapai Lethal Dosis $50 \quad\left(L_{50}\right)$ pengamatan dengan jumlah nyamuk Aedes aegypti yang mati rata -rata mencapai 16 ekor (53 \%) dalam tiga kali pengulangan.

b. Mat serbuk bunga sukun dosis $300 \mathrm{mg}$ diinyatakan lebih efektif setelah 25 menit pengamatan mencapai Lethal Dosis 50 (LD 50$)$ dengan jumlah nyamuk yang mati rata - rata mencapai 16 ekor ( $53 \%$ ) dan juga pada 30 menit pengamatan Lethal Dosis 50 (LD50) dimana nyamuk yang mati rata - rata mencapai 20 ekor $(67 \%)$ dengan masing - masing tiga kali pengulangan.

\section{Saran}

a. Hasil penelitian ini diharapkan dapat menjadi suatu alternatif pengendalian vektor khususnya terhadap nyamuk Aedes aegypti, mat serbuk bunga sukun dapat difungsikan sebagai insektisida nabati.

b. Penelitian ini mengunakan mat serbuk bunga sukun diharapkan agar peneliti selanjutnya dapat meneliti tentang seberapa lama mat serbuk bunga sukun dapat bertahan .

c. Disarankan agar kiranya pengusaha dapat membuat anti nyamuk elektrik dengan bahan aktif mat serbuk bunga sukun agar lebih ramah lingkungan karena bahan kimia insektisida yang dihasilkan mempunyai zat aktif alami.

d. Untuk pemerintah atau petugas kesehatan dapat dijadikan sebagai sumber informasi dan pelatihan kepada masyarakat cara pembuatan mat bunga sukun untuk menggunakan bahan insektisida nabati yang ramah lingkungan.

\section{DAFTAR PUSTAKA}

Kardinan, A .2004.Pestisida Nabati, Ramuan \& Aplikasi. Jakarta: Penebar Swadaya.

Lumowa, Sonja V.T.2013.Pengaruh Mat Serbuk Bunga Sukun (Artocarpus Altilis L.) Sebagai Isi Ulang Anti Nyamuk Elektrik Terhadap Kematian Nyamuk Aedes Aegypti L. jurnal Fakultas Universitas Mulawarman Samarinda. (Online). http ://jurnal .fkip. uns.ac. id/index.php/prosbio/article/view/3110. Di akses pada 24 januari 2017 pukul 14.00 WITA.

Notoatmodjo, Soekidjo .2005.Metodologi Penelitian Kesehatan.Cetakan Ketiga. Jakarta: Rineka Cipta.

Purnomo, Edi et al,.2011.Mat Bunga Sukun sebagai Alternatif Anti Nyamuk.Karya Ilmiah Kementrian Agama Madrasah Aliyah Negeri (MAN) Negara, Bali. (Online). https://butiranhikmah.files.wordpress.com/2013/01/kir upi manfaat-bungasukun. pdf/. Di akses pada 24 Januari 2017 pukul 14.00 WITA.

Republik Indonesia .2010. Peraturan Menteri Kesehatan Republik Indonesia Nomor : 374/MENKES/PER/III/2010 Tentang Pengendalian Vektor 
Jurnal Sulolipu : Media Komunikasi Sivitas Akademika dan Masyarakat

Vol. 17 No.II 2017

e-issn : 2622-6960, p-issn : 0854-624X

Sembel, Dantjhe T,.2010.Pengendalian Hayati. Yogyakarta: Andi.

Sitorus, Memory Fitri et al,.2013, Pemanfaatan Daun Tanaman Sukun (Artocarpus Altilis) Sebagai Anti Nyamuk Mat Elektrik Dalam Membunuh Nyamuk Aedes Spp.Fakultas Kesehatan Masyarakat Universitas Sumatera Utara Departemen Kesehatan Lingkungan.(Online). http://repository. usu.ac.id/bitstream/ handle/123456789/47097/ Cover.pdf;sequence=7. Di akses pada 24 januari 2017 pukul 13.00 WITA.

Sumantri, Arif.2015.Kesehatan Lingkungan .Edisi Ketiga.Jakarta: Kencana Prenada Media Group.

Suwito et al,.2015. Petunjuk Teknis Pemakaian Rapid Diagnosis Tes (RDT) DBD Dan Chikungunya.Jakarta: Direktorat Pengendalian Penyakit Bersumber Binatang Dirjen P2PL.

WHO.2005.Panduan Lengkap Pencegahan Dan Pengendalian Dengue Dan Demam Berdarah.Jakarta: EGC. 